\title{
Nitrogen fertilization, botanical composition and biomass production on mixed-grass rangeland
}

\author{
MARILYN J. SAMUEL AND RICHARD H. HART
}

\begin{abstract}
Authors are former botanist and rangeland acientist, USDA-ARS, High Plains Grasslands Research Station, 8408 Hildreth Road, Cheyenne, Wyo. 82009.
\end{abstract} Samuel's present address is 1203 Third St. East, Lehigh Acres, Fla. 33972.

\begin{abstract}
Many studies have reported nitrogen $(N)$ fertilization of rangeland, but few have reported changes in botanical composition, which may be as important as changes in forage production, or were continued for as long as 14 years. We determined frequency of occurrence of over 90 plant species in 1976-1988 under rates of 0,22 , or $34 \mathrm{~kg} \mathrm{~N} \mathrm{ha}^{-1}$ applied in spring or fall to mixed-grass rangeland in southeast Wyoming; frequency of 23 species will be reported. We also determined total biomass production and production of major species and species groups in 1982-1988. Blue grama Bouteloua gracilis (H.B.K.) Griffiths] frequency decreased during years 5 through 7 because of the interaction of $\mathbf{N}$ and drought. The effects of long-term application of $\mathbf{N}$ decreased blue grama in year 12 and beyond. Nitrogen fertilization increased frequency of western wheatgrass [Pascopyrum smithii (Rydb.) A. Love] in all years except the driest year of the study. Needleleaf sedge [Carex eleocharis Bailey] decreased because grazing had been removed from the study area; this occurred sooner and to a greater extent on fertilized than on unfertilized plots. Fourteen other perennial species were quite variable in response to the 3 rates and the 2 seasons of application. Frequency of 6 annual species fluctuated greatly among years and treatments. Nitrogen fertilization did not increase average forage production enough to be profitable for cattle production.
\end{abstract}

Key Words: Bouteloua gracilis, native forbs, Pascopyrum smithii, range fertilization, steer gains, stocking rate

Increases in forage production have been reported from many studies of nitrogen ( $N$ ) fertilization on native range in the central and northern Great Plains (Black 1968; Black and Wight 1979; Burzlaff et al. 1968; Goetz 1969; Houston 1971; Houston and Hyder 1975; Houston et al. 1973; Jacobsen et al. 1996; Klages and Ryerson 1965; Lorenz 1977; Lorenz and Rogler 1972, 1973a, 1973b; Power 1980a, 1980b, 1985; Power and Alessi 1971; Power and Legg 1984; Rauzi 1978, 1979; Rauzi and Fairbourn 1983; Rogler and Lorenz 1966; Samuel et al. 1980; Smika et al. 1965; Smoliak 1965; Wight 1975, 1976; Wight and Black 1979) and in the review of Rogler and Lorenz (1974). These studies included very low to very high $\mathrm{N}$ rates, usually applied for only a few years.

Authors wish to thank Frank Rauzi and Merle L. Fairbourn for originating this study and laying out plots large enough for our sampling. We especially appreciate their early work on this study (1974-1981).

Manuscript accepted 21 Sept. 1997.
Only a few reported botanical composition changes (Goetz 1969; Houston and Hyder 1975; Klages and Ryerson 1965; Lorenz 1977; Lorenz and Rogler 1972; Rauzi 1978, 1979; Rauzi and Fairbourn 1983; Wight 1975, 1976). On rangeland in southwestern North Dakota, application of 37,74 , or $112 \mathrm{~kg} / \mathrm{ha}$ of $\mathrm{N}$ for 3 years reduced cover of blue grama [Bouteloua gracilis (H.B.K.) Griffith's] and increased cover and density of western wheatgrass [Pascopyrum smithii (Rydb.) A. Love] and Artemisiu spp. (Goetz 1969).

Lorenz and Rogler (1972) reported decreases in blue grama and increases in western wheatgrass after 11 years of annual applications of $90 \mathrm{~kg} \mathrm{~N} \mathrm{ha}^{-1}$. Rogler and Lorenz (1974) increased the condition of depleted mixed-grass prairie rangeland from poor to excellent in 3 years, primarily by an increase in cool-season midgrasses, by annual application of $45 \mathrm{~kg} \mathrm{~N} \mathrm{ha}^{-1}$.

On overflow range sites in southeastern Montana, single fall applications of 33 or $101 \mathrm{~kg} \mathrm{~N} \mathrm{ha}^{-1}$ increased western wheatgrass production by $100 \%$ and $125 \%$ and production of all perennial grasses by $75 \%$ and $110 \%$, respectively (Houston 1971). On other range sites, production increased only in the year after $\mathrm{N}$ application. Density of western wheatgrass culms increased from 331 to $1,476 \mathrm{~m}^{-2}$ after application of $336 \mathrm{~kg} \mathrm{~N} \mathrm{ha}^{-1}$ (Wight 1976). On the other hand, Wight and Black (1979) reported little difference in species composition between unfertilized mixed-grass rangeland in eastern Montana and rangeland fertilized with $45 \mathrm{~kg} \mathrm{~N} \mathrm{ha}^{-1}$ for 10 years.

On mixed-grass prairie in southeastern Alberta, species composition of the plant community was unchanged at low $\mathrm{N}$ rates (Smoliak 1965). At medium and high rates, blue grama, needleandthread [Stipa comata Trin. \& Rupr.], prairie junegrass [Koeleria cristata (L.) Pers.], and clubmoss [Selaginella spp.] decreased while western and thickspike [Elymus lanceolatus (Scribn. \& J.G.Smith) Gould] wheatgrasses increased, and weeds often invaded. Cosper and Thomas (1961), Hyder and Bement (1964) and Patterson and Youngman (1960) found that weeds often increased in response to $\mathrm{N}$ to the extent that desirable species could not compete. Cool-season weedy grasses, including annual bromegrasses [Bromus spp.], sixweeks grass [Vulpia octoflora (Walt.) Rydb.] and Kentucky bluegrass [Poa pratensis L.] were especially troublesome.

In southeastern Wyoming, Rauzi (1978) reported significant changes in botanical composition after $672 \mathrm{~kg} \mathrm{~N} / \mathrm{ha}$ was applied at 1 time or equally over 4 years. Only the increase in western wheatgrass was beneficial. Decreases in blue grama and buffalo grass [Buchloë dactyloides (Nutt.) Engelm.] and increases in annual forbs were considered undesirable. 
Perennial grasses in pure stands differ widely in their growth response to $\mathrm{N}$, particularly at low levels. At $45 \mathrm{~kg} \mathrm{~N} \mathrm{ha}^{-1}$, the efficiency of $\mathrm{N}$ use (increase in dry matter production per $\mathrm{kg}$ of $\mathrm{N}$ applied) was 51 for intermediate wheatgrass [Elytrigia intermedia (Host) Nevski], 43 for crested wheatgrass [Agropyron cristatum (L.) Gaertn.], 39 for western wheatgrass, and 22 for Russian wildrye [Psathrostachys juncea (Fisch.) Nevski] (Power 1985). In another study, at $56 \mathrm{~kg} \mathrm{~N} \mathrm{ha}^{-1}$, efficiencies were 37 for intermediate wheatgrass, 26 for crested wheatgrass, 17 for western wheatgrass, 21 for Russian wildrye, 12 for beardless wheatgrass [Agropyron inerme (Scribn. \& Smith) Rydb.], 9 for green needlegrass [Stipa viridula Trin.], and 6 for thickspike wheatgrass (Jacobsen et al. 1996). These differences may be even greater when grasses grow in competition in mixed stands, where those that respond most strongly to $\mathrm{N}$ would be expected to increase at the expense of those that respond less strongly.

Our objective was to determine the effect of yearly, low-rate $\mathrm{N}$ fertilization on the botanical composition of mixed-grass rangeland. In addition, we intended to calculate whether the anticipated increase in forage production and the resulting estimated increases in cattle gains would be sufficient to make fertilization profitable. Cattle preference, herbage production, crude protein content, mineral concentrations, and water use have been reported previously for the first 5 years of the study (Samuel et al. 1980, Rauzi and Fairbourn 1983).

\section{Study Area and Methods}

The study site is within a 4-ha exclosure on the High Plains Grasslands Research Station approximately $8 \mathrm{~km}$ west of Cheyenne, Wyo. The topography is rolling hills of mixed-grass prairie at approximately $1,940 \mathrm{~m}$ elevation. The soil is Altvan loam, a mixed, mesic Aridic Argiustoll (Stevenson et al. 1984). The 114 year average precipitation was $371 \mathrm{~mm}$ with $73 \%$ falling between 1 April and 30 September (NOAA 1871-1988).

The experimental design was a randomized block with 5 treatments in $24 \times 30 \mathrm{~m}$ plots and 3 replications. Nitrogen in the form of ammonium nitrate was applied annually at rates of 22 and 34 $\mathrm{kg} \mathrm{N} / \mathrm{ha}$ in late October (F) or late March $(\mathrm{S})$; the fifth treatment was a $0 \mathrm{~N}$ check. Fertilization started in the fall of 1974 and continued through the spring of 1981 . Nitrogen was not applied in the fall of 1981 or spring of 1982 . Fertilization was reinstated in the fall of 1982 and continued through the duration of the study. Plots were not grazed, except for a few days each year in 1975-1979 during a grazing preference study (Samuel et al. 1980).

Frequency of occurrence was used to determine changes in botanical composition. Nested quadrats, 5.1 and $40.6 \mathrm{~cm}^{2}$, were located 25 times along each of 10 transects within each experimental plot (Hyder et al. 1965). Plots were sampled in June of each year starting the second year of fertilization (1976) through the 14th year (1988). The $5.1 \mathrm{~cm}^{2}$ quadrats were used to determine frequency of the major species: blue grama, western wheatgrass, and needleleaf sedge. The $40.6 \mathrm{~cm}^{2}$ quadrat was used to determine frequency of all other species. Common perennial species were scarlet globemallow [Sphaeralcea coccinea (Pursh) Rydb.], needleandthread, fringed sagewort [Artemisia frigida Willd.] and Geyer larkspur [Delphinium geyeri Greene]. Minor perennial species are listed in Table 2. Annual species present at significant frequencies were common sixweeksgrass, slimleaf goosefoot [Chenopodium leptophyllum Nutt.], bluebur stickseed [Lappula redowski (Hornem.) Greene], and those listed in Table 1. Approximately 60 additional species were uncommon or rare on these plots.

Beginning in 1982, above-ground biomass was sampled at approximately the time of peak standing crop, in late July or early August. Five $0.178-\mathrm{m}^{2}$ quadrats were placed at random along 1 diagonal of each plot. Vegetation was clipped to ground level; separated into blue grama, western wheatgrass, needleleaf sedge, other grasses, annual forbs, and perennial forbs (annual and perennial forbs were not separated in 1982 and 1983); dried at $50-60^{\circ} \mathrm{C}$ and weighed.

Vegetative height of 100 plants per plot of blue grama and western wheatgrass were measured for study during years 10 through 13. Blue grama seed heads were counted in years 10 and 12 .

Frequency of occurrence and biomass data were subjected to analysis of variance; where significant differences were detected, Tukey's highest significant differences (Tukey 1953) were calcu-

Table 1. Frequency of minor forb species on unfertilized plots compared to average frequency on the 4 nitrogen fertilization treatments; generalized reactions, 1976-1988.

\begin{tabular}{|c|c|c|c|c|c|c|c|c|c|c|c|c|c|c|}
\hline \multicolumn{2}{|l|}{ Species } & \multicolumn{12}{|c|}{ 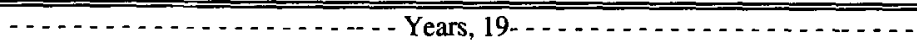 } & 88 \\
\hline Perennials & $(\%)$ & \multicolumn{13}{|c|}{$\ldots \ldots \ldots \ldots$ (Frequency response ${ }^{1}$ ) $\ldots \ldots \ldots$} \\
\hline $\begin{array}{l}\text { Combleaf evening primrose [Oenothera coronopifolia } \\
\text { Torr. \& Gray] }\end{array}$ & $0-29$ & ns & ns & ns & ns & $+^{*}$ & ns & $+*$ & $+*$ & $+*$ & $+^{*}$ & $+*$ & $+*$ & $t^{*}$ \\
\hline I ow fleabane [Erigeron pumilus Nutt.] & $0-25$ & ns & ns & ns & ns & $=$ & $=$ & ns & + & $+*$ & $+*$ & $+*$ & $+*$ & $+*$ \\
\hline Plains wallflower [Erysimum asperum (Nutt.) DC.] & $0-26$ & ns & ns & ns & ns & ns & ns & ns & $+*$ & + & + & + & + & + \\
\hline Drummond milkvetch [Astragalus drummondii Dougl.] & $1-11$ & ns & ns & ns & + & + & ns & $\mathrm{ns}$ & + & + & + & + & + & $t^{*}$ \\
\hline Scarlet gaura [Gaura coccinea Nutt. ex Pursh] & $1-15$ & + & ns & ns & + & ns & ns & + & + & + & + & + & + & + \\
\hline Rush skeletonplant [Lygodesmia junceae (Pursh) D. Don] & $2-33$ & + & ns & ns & + & ns & ns & ns & ns & ns & $=$ & $=$ & $=$ & $=$ \\
\hline Lanceleaf bluebells [Mertensia lanceolata (Pursh) A. DC.] & $1-26$ & $=$ & ns & $=$ & $=$ & ns & $=$ & $=$ & $=$ & $=$ & $=$ & $=$ & $=$ & $=$ \\
\hline Lambstongue groundsel [Senecio integerrimus Nutt.] & $0-24$ & ns & ns & ns & ns & $=$ & - & - & - & - & - & - & - & - \\
\hline Textile onion [Allium textile Nels. \& MacBr.] & $0-35$ & ns & ns & - & ns & ns & - & ns & ns & + & ns & ns & ns & ns \\
\hline \multicolumn{15}{|l|}{ Annuals } \\
\hline Creeping draba [Draba reptans (Lam.). Fern.] & $0-48$ & ns & ns & - & ns & - & - & ns & $=$ & - & - & + & + & + \\
\hline Flixweed tansymustard [Descuraina sophia (L.) Webb.]. & $0-54$ & ns & ns & ns & + & + & ns & ns & $=$ & ns & ns & ns & $=$ & - \\
\hline Prairie pepperweed [Lepidium densiflorum Schrad.] & $0-27$ & ns & $=$ & $=$ & $=$ & - & - & ns & - & - & ns & - & $=$ & - \\
\hline
\end{tabular}

Frequency on $0 \mathrm{~N}$ was: $+^{*}$, significantly higher than on all $\mathrm{N}$ treatments; + , higher than on all $\mathrm{N}$ treatments, one or more significantly so; $=$, higher than on some $\mathrm{N}$ treatments, lower than some; - lower than on all $\mathrm{N}$ treatments, one or more significantly so; ns, not significantly different from any $\mathrm{N}$ treatment. 
lated at the $\mathrm{P}<0.05$ level; all differences mentioned in the text are significant unless otherwise described. Plant heights and seed head numbers were subjected to analysis of variance and means were separated with Tukey's $w$ procedure (Steel and Torrie 1960).

\section{Results and Discussion}

\section{Major Perennial Species}

\section{Blue grama}

Blue grama frequency decreased under all fertilizer treatments in $1979-81$ and $1987-88$ (Fig. 1 ), and under $34 \mathrm{~F}$ in all years except 1976. Blue grama is a warm-season $\left(\mathrm{C}_{4}\right)$ species; all the major competing species (western wheatgrass, needleleaf sedge and scarlet globemallow) are cool-season $\left(C_{3}\right)$ species (Dickinson and Dodd 1976). When temperatures warm in the spring, the $N$ from $34 \mathrm{~F}$ was available for these cool-season species. Nitrogen in the spring applications may not have been as available in all years because there may not have been enough time and/or precipitation for incorporation of the $\mathrm{N}$ into the system after application in late March.

Dickinson and Dodd (1976) studied the phenology of shortgrass prairie species at 3-day intervals during 1972 at a site about $55 \mathrm{~km}$ southeast of our site. When they started their observations on 1 April, the same $C_{3}$ species that are in our study were already growing, but blue grama didn't start growth until 30 April.

Cool-season species may start growth even earlier than normal because of the extra $\mathrm{N}$ and utilize even more of the soil moisture. Lorenz and Roglcr (1973a) reported earlier growth of mixed prairie vegetation in the presence of $45 \mathrm{~kg} N / \mathrm{ha}$. Therefore, when the weather was warm enough for blue grama to grow, moisture may have been more limiting on some of the $\mathrm{N}$ plots. Boryslawski and Bentley (1985) found that $N$ fertilization increased competitiveness of western wheatgrass with blue grama at day/night temperatures of $20 / 15^{\circ} \mathrm{C}$ but not at $30 / 15^{\circ} \mathrm{C}$. Hyder et al. (1975) found that $\mathrm{N}$ fertilization increased the severity of drought on blue grama.

Although 1979 was the driest year during our study (Fig. 2), blue grama frequency under $\mathrm{N}$ fertilization (mean of 4 treatments) was not the lowest until 1980. Frequency sampling was done in early June, but blue grama makes most of its growth during the warmer weather after that. Therefore, the full effect of the 1979 reduction in precipitation on blue grama frequency was not seen until 1980. The differences seen in 1979-81 may have been responses to the interaction of $\mathrm{N}$ and dry conditions; these differences became smaller during the following normal and wet years.

In 1987 and 1988, long-term addition of $\mathrm{N}$ to the system contributed to a precipitous decline in the frequency of blue grama despite normal precipitation. Lorenz and Rogler (1972) reported a decrease in blue grama basal cover from 34 to $25 \%$ during 8 years in which $45 \mathrm{~kg} \mathrm{~N} \mathrm{ha}^{-1}$ were applied each fall. Hyder et al. (1975) reported a decrease in blue grama frequency after 2 years of fall application of $22 \mathrm{~kg} \mathrm{~N}^{-1}$, but this followed a record dry year with only $35 \%$ of normal rainfall. Rauzi (1978) reported little change in the percentage of total composition contributed by blue grama, forbs, and dryland sedges in the first 2 years of applying $180 \mathrm{~kg} \mathrm{~N} \mathrm{ha}{ }^{-1}$, but western wheatgrass increased and buffalograss decreased in the first and second years of fertilization. In the third and succeeding years, blue grama decreased and forbs increased, but needleleaf sedge showed no consistent response to $\mathrm{N}$ fertilization. On the other hand, Wight and Black (1979) applied $45 \mathrm{~kg} \mathrm{~N}$ $\mathrm{ha}^{-1}$ to mixed-grass prairie in Montana, and found few significant effects on botanical composition in any of the 10 years of their study.

Blue grama biomass followed much the same pattern as frequency, with 2 exceptions. Biomass on the $0 \mathrm{~N}$ check was significantly lower than that on any $\mathrm{N}$ treatment in 1985 , when there were no differences among treatments in frequency. In 1987 and 1988 , there were no differences in biomass among treatments, but frequency on $0 \mathrm{~N}$ plots was higher than that on all $\mathrm{N}$ treatments. Biomass can be regarded as a product of frequency of occurrence times vigor or size of individual plants; therefore frequency alone is not a reliable indicator of biomass production.

Vegetative height of blue grama was greater in the $\mathrm{N}$ plots than on the $0 \mathrm{~N}$ plots across all 4 years when height was measured (Table 2). Height varied among years more than among treatments, because of variable climatic conditions, but we found no significant year $\times$ treatment interactions.

The number of blue grama seedheads, counted in 1984 and 1986, did not differ among $\mathrm{N}$ levels (Table 2). There were more seedheads in 1984, following a wet year, than in 1986, following a dry year. Seedheads numbers were not large enough to count in 1985 and 1987. Seed head production is dependent on adequate precipitation (Dickinson and Dodd 1976).

\section{Western wheatgrass}

Frequency of western wheatgrass was higher on all $\mathrm{N}$ treatments than on the check in every year except for the dry year, 1979, when frequency on $22 \mathrm{~S}$ was no higher than on $0 \mathrm{~N}$ (Fig. 1). Frequency on $34 \mathrm{~F}$ was higher than on $22 \mathrm{~S}$ or $22 \mathrm{~F}$ in $1976-78$, but there were no differences among $\mathrm{N}$ treatments in any later year. Both frequency and biomass of western wheatgrass reached a maximum in 1983, the wettest year in the study. Biomass on most or all $\mathrm{N}$ treatments was higher than on $0 \mathrm{~N}$ in all years but 1985, when there were no significant differences among treatments.

Houston (1971) found that fertilization with $34 \mathrm{~kg} \mathrm{~N} \mathrm{ha}^{-1}$ increased western wheatgrass production by $35 \%$ in 1958 and $143 \%$ in $1959 ; 34 \mathrm{~kg} \mathrm{~N} \mathrm{ha}^{-1}$ increased the proportion of western wheatgrass in total perennial grasses from 66 to $76 \%$ in 1958 and from $80 \%$ to $94 \%$ in 1959 . Smika et al. (1965) reported. "At the close of the study, western wheatgrass was the predominant species on the plots receiving heavy applications ( 90 or $180 \mathrm{~kg} \mathrm{ha}^{-1}$ ) of $\mathrm{N}$."

Table 2. Fertilizer rate and year effects on vegetative heights of blue grama and western wheatgrass, years 1984-1987, and number of blue grama seedheads, 1984 and 1986.

\begin{tabular}{|c|c|c|c|}
\hline \multirow[b]{2}{*}{ Treatment, year } & \multicolumn{2}{|c|}{ Height } & \multirow[b]{2}{*}{$\begin{array}{r}\text { Blue } \\
\text { grama }\end{array}$} \\
\hline & $\begin{array}{l}\text { Blue } \\
\text { grama }\end{array}$ & $\begin{array}{l}\text { Westem } \\
\text { wheatgrass }\end{array}$ & \\
\hline & $(\mathrm{cm})$ & \multicolumn{2}{|c|}{${\text { (heads } \mathrm{m}^{-2\}}}^{-2}$} \\
\hline \multicolumn{4}{|l|}{ Treatments } \\
\hline Unfertilized & $6.9 \mathrm{y}$ & $21.9 \mathrm{c}$ & $6.3 \mathrm{a}$ \\
\hline $22 \mathrm{~kg} \mathrm{ha}^{-\mathrm{I}}$, fall & 10.1 & $23.8 \mathrm{bc}$ & $13.05 \mathrm{a}$ \\
\hline $22 \mathrm{~kg} \mathrm{ha}^{-1}$, spring & $10.0 x$ & $25.7 \mathrm{ab}$ & $13.25 \mathrm{a}$ \\
\hline $34 \mathrm{~kg} \mathrm{ha}^{-1}$, fall & $10.4 x$ & $26.2 \mathrm{a}$ & $15.95 \mathrm{a}$ \\
\hline $34 \mathrm{~kg} \mathrm{ha}^{-1}$, spring & $10.3 x$ & $25.7 \mathrm{ab}$ & $16.95 \mathrm{a}$ \\
\hline \multicolumn{4}{|l|}{ Years } \\
\hline 1984 & $8.4 \mathrm{z}$ & $26.2 a$ & $24.8 \mathrm{a}$ \\
\hline 1985 & $9.2 \mathrm{y}$ & $21.3 \mathrm{c}$ & - \\
\hline 1986 & $10.5 x$ & $24.5 b$ & $1.4 \mathrm{~b}$ \\
\hline 1987 & $10.0 \mathrm{x}$ & $26.6 \mathrm{a}$ & - \\
\hline
\end{tabular}

a,b,x.y etc.; Means in the same column, within "Treatments" or "Years" sections, followed by the same letter, are not significantly different $(P<0.01)$. 

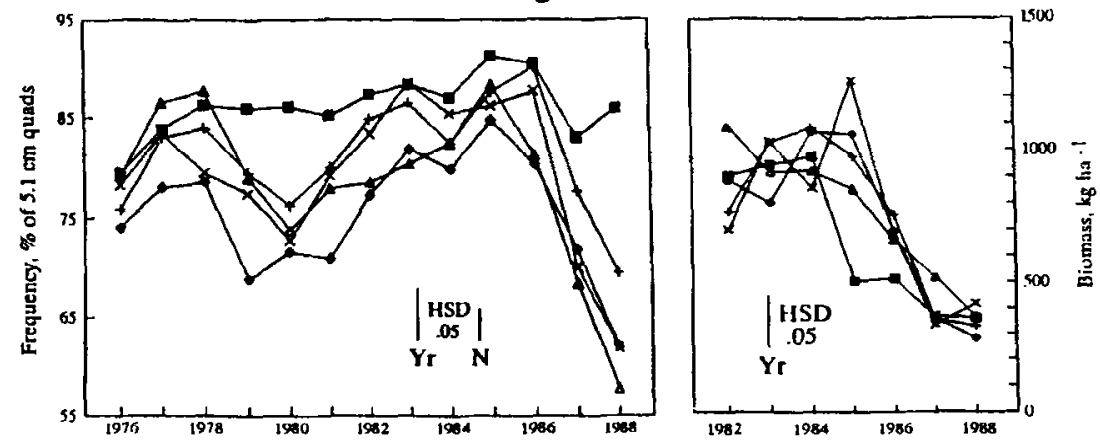

Western wheatgrass
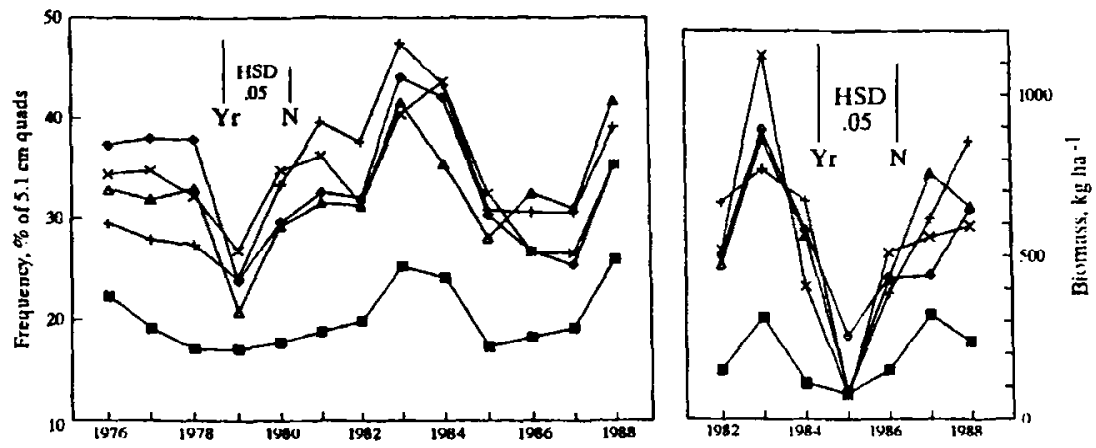

Needleleaf sedge

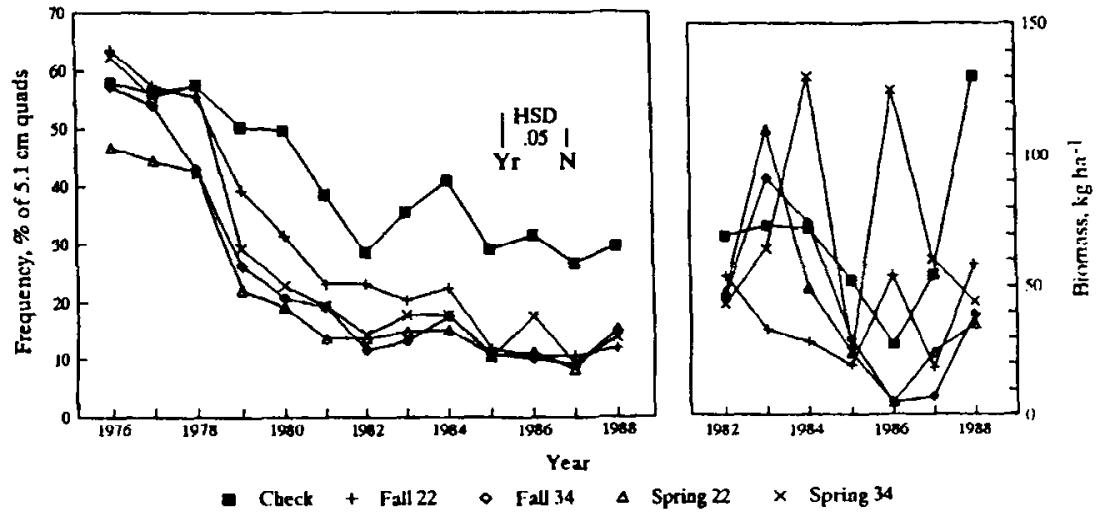

Fig. 1. Frequency (5.1 $\mathrm{cm}^{2}$ quadrats), 1976-1988, and biomass, 1982-1988, of blue grama, western wheatgrass, and needleaf sedge; response to rate and season of annual $N$ application.

Lorenz and Rogler (1972) reported that, across the 8 years of their study, western wheatgrass density averaged 50 stems $\mathrm{m}^{-2}$ on unfertilized rangeland vs. 314 stems $\mathrm{m}^{-2}$ on plots fertilized at $45 \mathrm{~kg} \mathrm{~N} / \mathrm{ha}$.

Western wheatgrass vegetative shoots were taller on $22 \mathrm{~S}, 34 \mathrm{~S}$ and 34F $\mathrm{N}$ than on the other treatments (mean of 1984-87; Table 2). Shoot height varied with years and appeared to be closely correlated with precipitation in the 12 months before sampling (Fig. 2). The responses of western wheatgrass frequency and shoot height to $\mathrm{N}$ rate were not the same because height and frequency reflect different ecological processes and therefore react differently to the same input (Addicott et al. 1987).

\section{Needleleaf sedge}

Needleleaf sedge decreased greatly during the 14 years, especially with $\mathrm{N}$ fertilization. Since 1979 , frequency of needleleaf sedge was lower on all $N$ treatments than on $0 N$ (Fig. 1). Grazing was excluded from the fertilized plots except for a grazing behavior study conducted for a few weeks each during 1975 through 1977 (Samuel et al. 1980). Needleleaf sedge is an increaser under grazing by cattle (Stevenson et al. 1984) and might be expected to decrease when grazing is excluded.

Biomass of needleleaf sedge was highly variable among treatments and from year to year, and no conclusions can be drawn relative to the general effect of $\mathrm{N}$ fertilization. Needleleaf sedge 


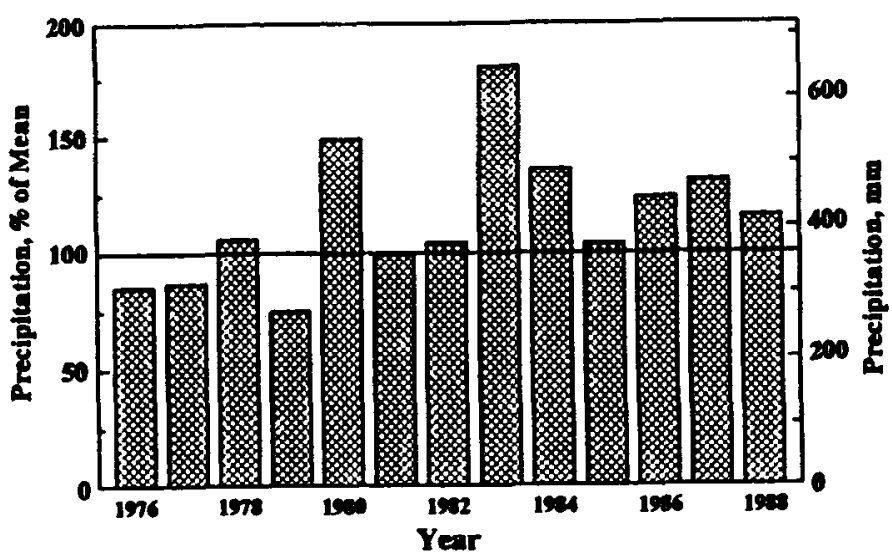

Fig. 2. Total precipitation, July-June, in 12 months before sampling.

is a minor component compared to blue grama and western wheatgrass.

\section{Other perennial species}

Needleandthread is a decreaser under grazing. Because the grazing pressure was removed from the plot area, needleandthread frequency increased from a mean of $10 \%$ across all treatments in 1976 to $23 \%$ in 1988 (Fig. 3). From 1976 to 1980 , frequency was higher on $22 \mathrm{~F}$ than on other treatments; thereafter differences among treatments were few and inconsistent.

Frequency of prairie junegrass was low initially, then increased greatly on $22 \mathrm{~S}$ and $22 \mathrm{~F}$ in $1985-1988$, and on the $0 \mathrm{~N}$ check in 1986-1988 (Fig. 3). This increase may reflect reduced competition from blue grama, which decreased in the same years. Frequency of prairie junegrass remained low on 345 and 34F.

Fringed sagewort frequency did not differ among treatments 1976-1978 (Fig. 3). From 1979 through 1983, frequency on some $\mathrm{N}$ treatments was higher than on the $0 \mathrm{~N}$ check, but thereafter frequency was higher on the check. Frequency of fringed sagewort increased in 1983 with high precipitation and in later years, perhaps with decreased competition from blue grama.

Scarlet globemallow was the dominant forb in the study area. Frequency on the $0 \mathrm{~N}$ check was always higher than on $22 \mathrm{~S}$ and higher than on $22 \mathrm{~F}$ in 1976, 1981 and 1988 (Fig. 3). Frequency on $34 \mathrm{~S}$ seldom differed from that on the check, but frequency on $34 \mathrm{~F}$ was lower than that on the check in most years after 1983. Hyder et al. (1975) reported increases in frequencies of scarlet globemallow when $22 \mathrm{~kg} \mathrm{~N}^{-1}$ was applied in the fall, but that was on grazed rangeland.

\section{Major Annual Species \\ Sixweeks grass}

No differences among $\mathbf{N}$ treatments appeared until 1980 (Fig. 3). From 1980 through 1983, frequency on the treatments generally ranked $22 \mathrm{~S}>34 \mathrm{~S}=34 \mathrm{~F}>22 \mathrm{~F}>0$. No differences were seen among $22 \mathrm{~F}, 34 \mathrm{~F}$ and $34 \mathrm{~S}$ after 1983 , but frequency on $22 \mathrm{~S}$ was higher than on the other $N$ treatments 1986-1988, and frequency on the check was highest of all in 1987. The 1983 and 1987 peaks corresponded with above-average precipitation in those years, and the 1981 peak followed a year of above-average precipitation. Increases or decreases from the same rate of $\mathrm{N}$ during different years were also reported by Hyder et al. (1975) during their 8 year study. They concluded that climatic conditions were more important in population dynamics of this species than was soil fertility.

Sudden increases in populations of annual species may occur following a year of heavy seed production and/or in a year in which conditions are optimum during the short period of seed germination and seedling establishment. Favorable conditions for germination and establishment may occur even though total precipitation for the year is only average or less than average. Therefore it is difficult to explain population shifts from aggregated weather data, or from data on individual rainfall events when the period of germination and establishment is not known.

\section{Slimleaf goosefoot}

Peaks in slimleaf goosefoot frequency sometimes occurred in the same years as those of sixweeks grass and sometimes not (Fig. 3), illustrating the difficulty of explaining year-to-year shifts in the populations of annual plant species by shifts in total annual precipitation. Both species increased in 1983, but goosefoot also peaked in 1979 when frequency of sixweeks grass approached zero. Goosefoot frequencies peaked in 1987, but frequency of sixweeks grass increased sharply only on $22 \mathrm{~S}$ and $0 \mathrm{~N}$. Except in 1981 and 1984, goosefoot frequency was higher under $34 \mathrm{~S}$ and $34 \mathrm{~F}$ than under $0 \mathrm{~N}$; in 1979 and 1986-1988, frequency also was higher under $22 \mathrm{~S}$ and 22F. Hyder et al. (1975) reported fluctuations of slimleaf goosefoot frequency were enhanced by $\mathrm{N}$ fertilization.

\section{Bluebur stickseed}

Frequency of bluebur stickseed appeared to follow the same pattern under all treatments (Fig. 3). Frequency was higher on all $\mathrm{N}$ treatments than on the $0 \mathrm{~N}$ check in the peak years of 1980 and 1983 and in 1981, but in the peak year of 1987 only 22F showed higher frequency than the check, which showed higher frequency than $34 \mathrm{~F}$ or $34 \mathrm{~S}$. This reversal of check vs. $\mathrm{N}$ is similar to that seen for another annual, sixweeks grass. Hyder et al. (1975) reported an increase in blucbur stickseed with $\mathrm{N}$ fertilization in only 4 of the 8 years of their study, but populations were low with frequencies from 0 to $8 \%$.

\section{Other Forb Species}

Frequency of Geyer larkspur remained nearly the same on all treatments until 1987, when it began to increase on the $0 \mathrm{~N}$ check. Mean frequency of larkspur was 13.3 in 1977 and 13.9 in 1986 , with no differences among treatments. In contrast, frequencies were 24.1 on the check vs. a mean of 13.2 across all $\mathrm{N}$ treatments in 1987 and 33.7 and 14.3, respectively, in 1988.

The generalized responses of 9 perennial and 3 annual forbs on the unfertilized check compared to those under $\mathrm{N}$ fertilization are shown in Table 1. Combleaf evening primrose frequencies on the check were higher than on all $\mathrm{N}$ treatments in 1980 and 1982-1988, indicating a cumulative negative response to $N$ or to increased competition from other species which responded more favorably to $N$. Hyder et al. (1975) reported that combleaf evening primrose was nonresponsive to $22 \mathrm{~kg} \mathrm{~N} \mathrm{ha}^{-1}$ applied in the fall but that was under grazed conditions. Low fleabane frequencies on the check were higher than on all $\mathrm{N}$ treatments in the last 5 years of the study.

Plains wallflower, Drummond milkvetch and scarlet gaura showed higher frequencies on the check than on the $\mathrm{N}$ treatments as the study progressed, although differences were not always 

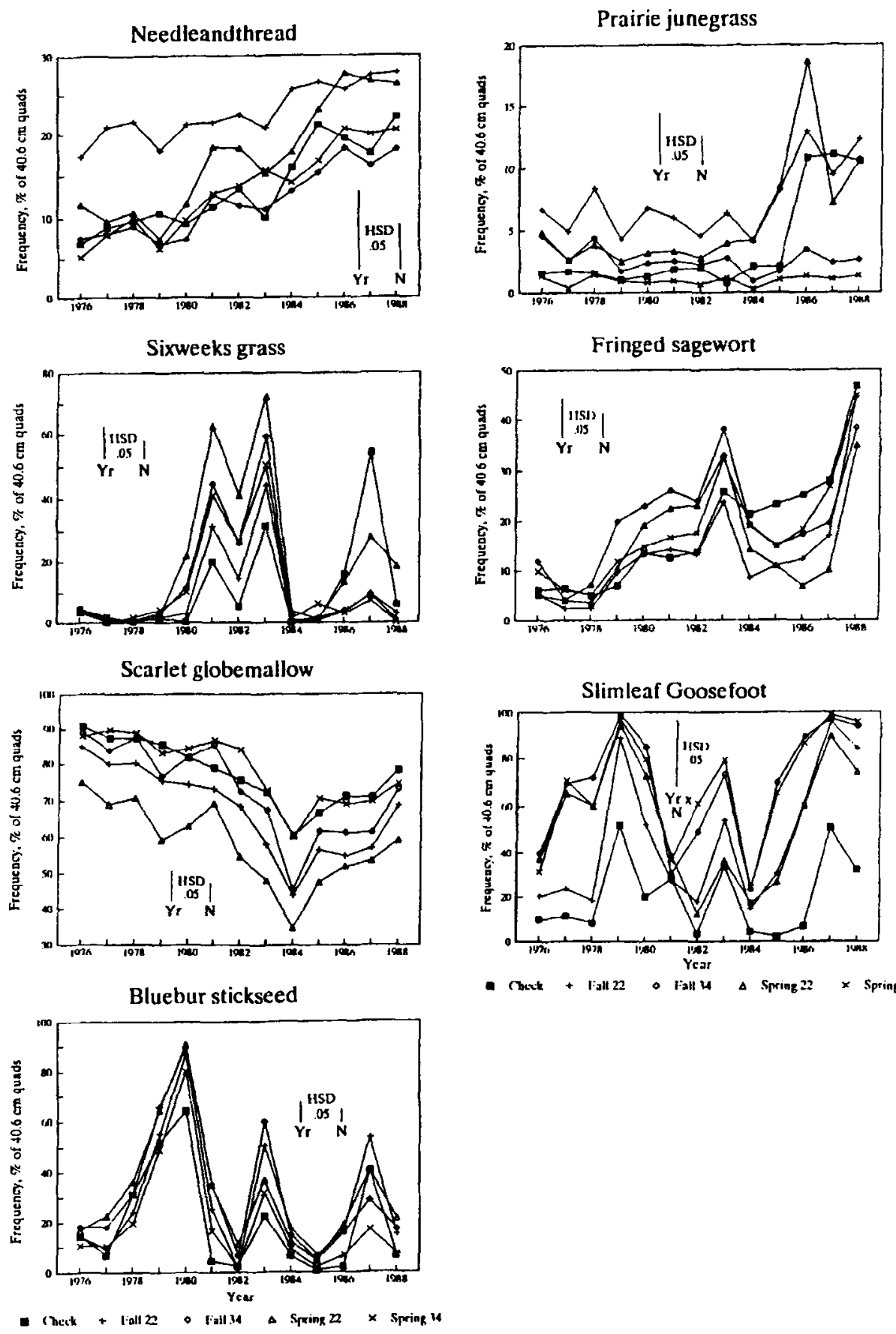

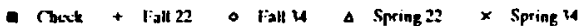

Fig. 3. Frequency $\left(40.6 \mathrm{~cm}^{2}\right.$ quadrats), 1976-1988, of needleandthread, prairie junegrass, sixweeks grass, fringed sagewort, scarlet globemallow, slimleaf goosefoot, and bluebur stickseed; response to rate and season of annual $\mathrm{N}$ application.

significant for every $\mathbf{N}$ treatment. Hyder et al. (1975) reported a

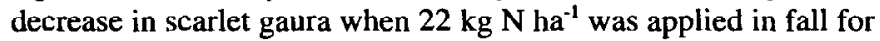
7 years. As our study progressed, frequencies of rush skeleton plant and lanceleaf bluebells became higher under some $\mathrm{N}$ treatments and lower under others. Frequency of lambs tongue groundsel was significantly lower on the check than on some $\mathbf{N}$ treatments.

Textile onion is a perennial but showed large yearly changes in frequency because it reproduces by seed in favorable years.
Frequency was lower on $0 \mathrm{~N}$ plots than on some $\mathrm{N}$ plots during 1978 and 1981 . Onion frequency became higher on the check than on some $\mathrm{N}$ plots in 1984, which was a wet year, but not in 1980 and 1983, which were even wetter. The increase in 1984 may reflect a favorable year for establishment, following a favorable year for seed production. Textile onion probably reacted to favorable climate more than to $\mathrm{N}$ level.

Creeping draba and flixweed tansy mustard did not react consistently to $\mathrm{N}$ and probably reacted more to climatic variables. 
Frequency of prairie pepperweed in $0 \mathrm{~N}$ plots was the same or lower than in some fertilized plots in years when there were differences. Hyder et al. (1975) reported increases in prairie pepperweed when $22 \mathrm{~kg} \mathrm{~N}^{-1}$ were applied in fall. They concluded that pepperweed populations increased over those on $0 \mathrm{~N}$ treatment because of $\mathrm{N}$ accumulation. No cumulative effects of $\mathrm{N}$ fertilization were seen in the present study.

\section{Total Above-ground Biomass (Peak Standing Crop)}

Total biomass 1982-1988 (Fig. 4) was very closely related to total precipitation in the 12 months before sampling (Fig. 2). Both were very high in 1983, average in 1982 and 1985, and above average in 1984 and 1986-1988. Biomass was higher on all $\mathrm{N}$ treatments than on the $0 \mathrm{~N}$ check in all years except 1982 , when it was higher only on $22 \mathrm{~F}$ and $34 \mathrm{~F}$. Significant differences among $\mathrm{N}$ treatments were seen only in 1983, when biomass was higher on 34F than on the other treatments, and 1988, when biomass was higher on $34 \mathrm{~S}$ and $34 \mathrm{~F}$ than on $22 \mathrm{~F}$.

Contributions of grasses other than blue grama and western wheatgrass, perennial forbs, and annual forbs (Fig. 4) to total biomass varied greatly from year to year. Other grasses responded strongly to N, except in 1984 when only $34 \mathrm{~F}$ produced more biomass of other grasses than the check, and in the dry years of 1982 and 1985 when no $N$ treatment produced more biomass than the check. Biomass of annual forbs increased greatly with $\mathrm{N}$ fertilization only in 1986-1988, with production higher on 34F and $34 \mathrm{~S}$ than on $22 \mathrm{~F}$ and $22 \mathrm{~S}$. Response of perennial forbs was extremely variable among $\mathrm{N}$ treatments, years, and replications; no significant differences among years or treatments could be detected.

\section{Total biomass}

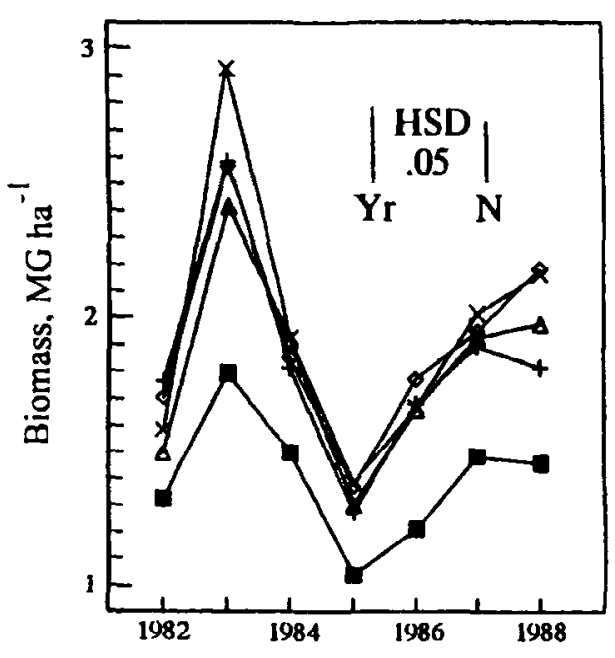

Peremnial forbs

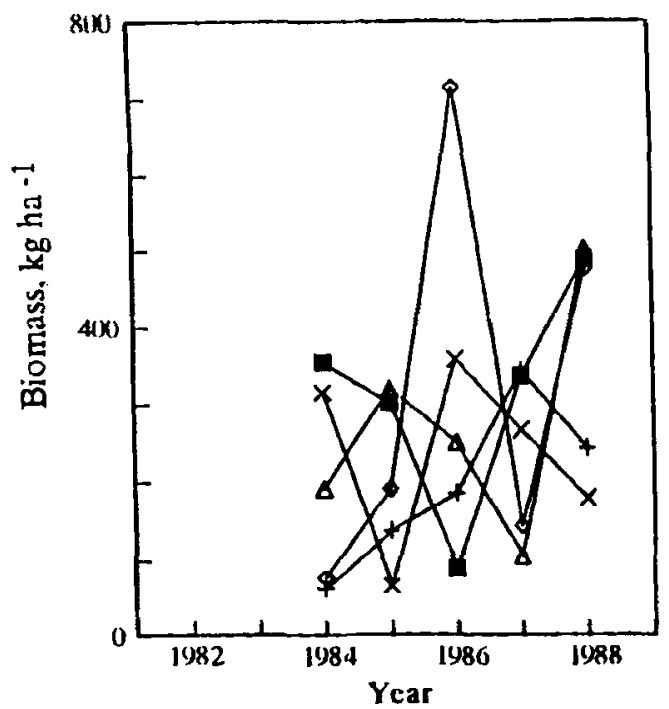

Other grasses

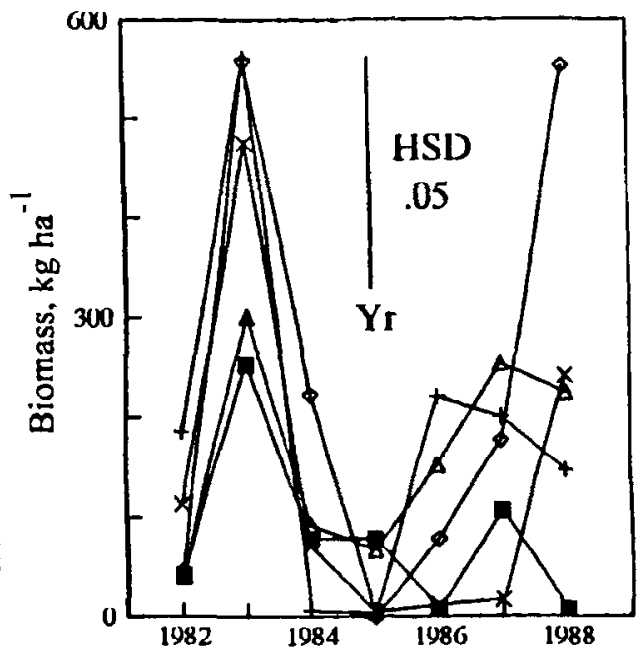

\section{Annual forbs}

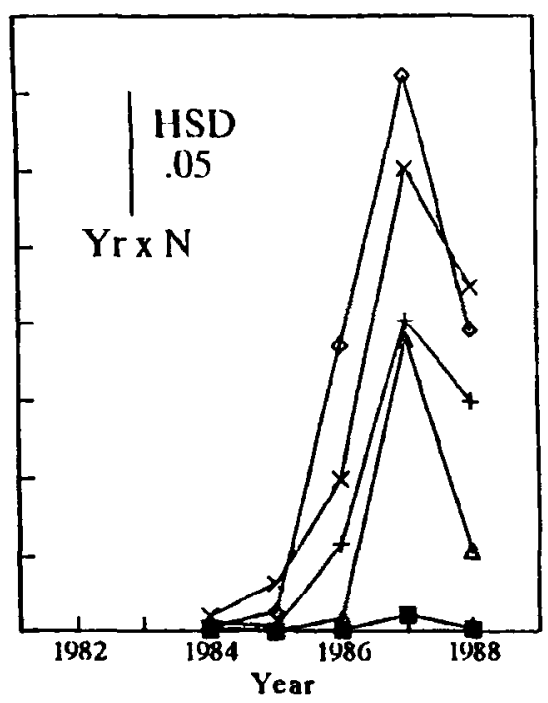

- Check + |'all $22 \circ$ [’al] 34

$\Delta$ Spring $22 \times$ Spring 34

Fig. 4. Biomass, 1982-1988, of other grasses, annual forbs, perennial forbs, and peak standing crop; response to rate and season of annual N application. 


\section{Estimated Animal Response}

Rogler and Lorenz (1966) stocked mixed-grass prairie fertilized with 0,45 , and $90 \mathrm{~kg} \mathrm{~N} \mathrm{ha-1}$ at $60.8,119.8$, and 153.9 steer-days $\mathrm{ha}^{-1}$, respectively, and achieved near-maximum gains averaging $0.86 \mathrm{~kg} \mathrm{day}^{-1}$ at all $3 \mathrm{~N}$ rates. Forage production averaged 2,215, 3,304 and $4,190 \mathrm{~kg} \mathrm{ha}^{-1}$. Stocking rates were never high enough to permit calculation of the optimum stocking rate, defined as the stocking rate which maximized return to land, labor and management (Hart 1978).

We used the STEERISK spreadsheet (Hart 1991) to calculate optimum stocking rates and return to land, labor and management in years of this study with good, average and poor forage production (Table 3). Parameters were initial steer weight of $275 \mathrm{~kg}$, purchase price $\$ 1.87$ and selling price of $\$ 1.65 \mathrm{~kg}^{-1}$ (\$0.85 and 0.75 $\left.\mathrm{lb}^{-1}\right)$, interest rate of $11 \%$, and grazing season of 150 days. STEERISK calculated an optimum stocking rate of 80.7 steerdays ha ${ }^{-1}$ at forage production of $2,500 \mathrm{~kg} \mathrm{ha}^{-1}$; Rogler and Lorenz (1966) stocked at only 60.8 steer-days ha ${ }^{-1}$ at forage production of $2,215 \mathrm{~kg} \mathrm{ha}^{-1}$. Fertilization is profitable only if the cost of purchasing and applying $N$ is less than the returns from increased animal production associated with increased forage production. We have called the cost at which this occurs the break-even cost of $N$. In a good year, at the steer costs shown in Table 3, $\mathrm{N}$ fertilization would be profitable if $N$ cost less than $\$ 0.40$ to $0.46 \mathrm{~kg}^{-1}$, but the break-even cost drops to $\$ 0.21$ to 0.22 in an average year and $\$ 0.14$ to 0.16 in a poor year. At present $\mathrm{N}$ costs $\$ 0.75$ to $0.90 \mathrm{~kg}^{-1}$, which does not include application costs, greatly exceeding the break-even cost of $\mathrm{N}$ even in a good forage year.

Applying $34 \mathrm{~kg} \mathrm{~N}^{-1}$ increased forage production by $954 \mathrm{~kg}$ $\mathrm{ha}^{-1}$ in a good forage year but only $340 \mathrm{~kg} \mathrm{ha}^{-1}$ in a poor year (Table 3). The site used in this study is more productive than average. Thirteen-year minimum, mean, and maximum estimates of forage production, averaged over a variety of unfertilized range sites at the High Plains Grasslands Research Station, were $540,1,120$, and $1,740 \mathrm{~kg} \mathrm{ha}^{-1}$ (Manley et al. 1997); comparable figures in this study were $1,039,1,451$ and $1,794 \mathrm{~kg} \mathrm{ha}^{-1}$.

Nitrogen fertilization of mixed-grass rangelands nearly always increased forage production, and sometimes increased cool-sea-

Table 3. Peak standing crops, optimum stocking rates, returns to land, labor and management (LLM) ${ }^{1}$ and break-even $N$ costs ${ }^{2}$ under fertilization with 0,22 , and $34 \mathrm{~kg} \mathrm{~N} \mathrm{ha}^{-1}$ in years with good, average and poor forage production.

\begin{tabular}{|c|c|c|c|c|c|}
\hline $\begin{array}{l}\text { Forage } \\
\text { production }\end{array}$ & & $\begin{array}{c}\text { Peak } \\
\text { standing } \\
\text { crop }\end{array}$ & $\begin{array}{l}\text { Optimum } \\
\text { stocking } \\
\text { rate }\end{array}$ & $\begin{array}{l}\text { Return } \\
\text { to LLM }\end{array}$ & $\begin{array}{c}\text { Break-even } \\
\text { N cost }\end{array}$ \\
\hline & $\left(\mathrm{kg} \mathrm{ha}^{-1}\right)$ & $\left(\mathrm{kg} \mathrm{ha}^{-1}\right)$ & (steer-day $\mathrm{ha}^{-l}$ ) & $\left(\$ \mathrm{ha}^{-1}\right)$ & $\left(\$ \mathrm{~kg}^{-1}\right)$ \\
\hline \multirow[t]{3}{*}{ Good } & 0 & 1794 & 57.9 & $\$ 25.58$ & \\
\hline & 22 & 2500 & 80.7 & 35.64 & $\$ 0.457$ \\
\hline & 34 & 2748 & 88.7 & 39.19 & 0.400 \\
\hline \multirow[t]{3}{*}{ Average } & 0 & 1451 & 46.8 & 20.70 & $\longrightarrow$ \\
\hline & 22 & 1793 & 57.9 & 25.57 & 0.221 \\
\hline & 34 & 1949 & 62.9 & 27.79 & 0.209 \\
\hline \multirow[t]{3}{*}{ Poor } & 0 & 1039 & 33.5 & 14.82 & - \\
\hline & 22 & 1289 & 41.6 & 18.38 & 0.162 \\
\hline & 34 & 1379 & 44.5 & 19.66 & 0.142 \\
\hline
\end{tabular}

Calculated with STEERISK (Hart 1991). Initial steer weight $275 \mathrm{~kg}$, purchase price $\$ 1.87 \mathrm{~kg}^{-1}$, selling price $\$ 1.65 \mathrm{~kg}^{-1},\left(\$ 0.85\right.$ and $0.75 \mathrm{lb}^{-1}$ respectively), interest rate $11 \%$, on pasture 150 days.

${ }^{2}$ Cost of purchasing and applying $\mathrm{N}$ must be less than break-even cost for returns on $\mathrm{N}$ fertilized rangeland to exceed returns on unfertilized rangeland. son grasses, which make up the major fraction of cattle diets (Samuel and Howard 1982). However, the increase in forage production is unlikely to increase cattle gains enough to be profitable, although $\mathrm{N}$ fertilization might increase cattle gains slightly because of increases in the proportion of preferred cool-season forage grasses. Nitrogen fertilization has been shown to increase grazing on areas under-utilized because of distance from water or topographic barriers (Samuel et al. 1980), but larger increases are likely to be achieved by fencing and water development (Hart et al. 1993). Nitrogen fertilization of mixed-grass prairie rangelands grazed by cattle is not profitable at present fertilizer and cattle prices.

\section{Literature Cited}

Addicott, J.F., J.M. Aho, M.F. Antolin, D.K. Padilla, J.S. Richardson, and D.A. Loluk. 1987. Ecological neighborhoods: scaling environmental patterns. Oikos 49:340-346.

Black, A. L. 1968. Nitrogen and phosphorus fertilization for production of crested wheatgrass and native grass in northeastern Montana. Agron. J. 60:213-216.

Black, A. L. and J. R. Wight. 1979. Range fertilization: nitrogen and phosphorus uptake and recovery over time. J. Range Manage. 32:349-353.

Boryslawski, Z. and B. L. Bentley. 1985. The effect of nitrogen and clipping on interference between $\mathrm{C} 3$ and $\mathrm{C} 4$ grasses. J. Ecol. 73:113-121.

Burzlaff, D. F., G. W. Fick, and L. R. Rittenhouse. 1968. Effect of nitrogen fertilization on certain factors of a western Nebraska range ecosystem. J. Range Manage. 21:21-24.

Cosper, H. R. and J. R. Thomas. 1961. Influence of supplemental runoff water and fertilizer on production and chemical composition of native forages. J. Range Manage. 14:292-297.

Dickinson, C.E. and J.L. Dodd. 1976. Phenological pattern in the shortgrass prairie. Amer. Midl. Natur. 96:367-378.

Goetz, H. 1969. Composition and yields of native grassland sites fertilized at different rates of nitrogen. J. Range Manage. 22:384-390.

Hart, R. H. 1978. Stocking rate theory and its application to grazing on rangelands, p. 550-553. In: D. N. Hyder (ed.) Proc. First Intl. Rangeland. Congress. Soc. Range Manage., Denver, Colo.

Hart, R. H. 1991. Managing livestock grazing for risk: the STEERISK spread sheet. J. Range Manage. 44:227-231.

Hart, R. H., J. Bissio, M. J. Samuel, and J. W. Waggoner Jr. 1993. Grazing systems, pasture size, and cattle grazing behavior, distribution and gains. J. Range Manage. 46:81-87.

Houston, W. R. 1971. Range improvement methods and environmental influences in the Northern Great Plains. USDA-ARS Prod. Res. Rep. 130. US Govt. Print. Off., Washington, DC.

Houston, W. R. and D. N. Hyder. 1975. Ecological effects and fate of $\mathrm{N}$ following massive $\mathbf{N}$ fertilization of mixed-grass plains. J. Range Manage. 28:56-60.

Houston, W. R., L. D. Sabatka and D. N. Hyder. 1973. Nitrate-nitrogen accumulation in range plants after massive $\mathrm{N}$ fertilization on shortgrass plains. J. Range Manage. 26:54-57.

Hyder, D. N. and R. E. Bement. 1964. Sixweeks fescue as a detertent to blue grama utilization. J. Range Manage. 17:261-264.

Hyder, D. N., R. E. Bement, E. E. Remmenga, and D. F. Hervey. 1975. Ecological responses of native plants and guidelines for management of shortgrass range. USDA Tech. Bull. 1503.

Hyder, D. N., R. E. Bement, E. E. Remmenga, and C. Terwilliger, Jr. 1965. Frequency sampling of blue grama range. J. Range Manage. 18:90-93.

Jacobsen, J. S., S. H. Lorbeer, H. A. R. Houlton, and G. R. Carlson. 1996. Nitrogen fertilization of dryland grasses in the Northern Great Plains. J. Range Manage. 49:340-345.

Klages, M. G. and D. E. Ryerson. 1965. Effect of nitrogen and irrigation on yield and botanical composition of western Montana range. J. Range Manage. 57:78-81. 
Lorenz, R. J. 1977. Changes in root weight and distribution in response to fertilization and harvest treatment of mixed prairie. p. 63-71 In: J. K. Marshall (ed.) The Belowground Ecosystem: A Synthesis of PlantAssociated Processes. Range Sci. Dept. Sci. Ser. 26, Colorado State Univ.

Lorenz, R. J. and G. A. Rogler. 1972. Furage production and botanical composition of mixed prairie as influenced by nitrogen and phosphorous fertilization. Agron. J. 64:244-249.

Lorenz, R. J. and G. A. Rogler. 1973. Growth rate of mixed prairie in response to nitrogen and phosphorus fertilization. J. Range Manage. 26:365-368.

Lorenz, R. J. and G. A. Rogler. 1973. Interaction of fertility level with harvest date and frequency on productiveness of mixed prairie. $J$. Range Manage. 26:50-54.

Manley, W. A., R. H. Hart, M. J. Samuel, M. A. Smith, J. W. Waggoner Jr., and J. T. Manley. 1997. Vegetation, cattle and economic responses to grazing strategies and pressures. J. Range Manage. $50: 638-646$.

National Oceanic and Atmospheric Administration (NOAA). 18711988. Climatological Data, annual summary, Cheyenne, Wyo. National Climatic Data Center, Asheville, N.C.

Patterson, J. K., and V. E. Youngman. 1960. Can fertilizers effectively increase our rangeland production? J. Range Manage. 13:255-257.

Power, J. F. 1985. Nitrogen- and water-use efficiency of several coolseason grasses receiving ammonium nitrate for 9 years. Agron. J. 77:189-192.

Power, J. F. 1980. Response of semiarid grassland sites to nitrogen fertilization: I. Plant growth and water use. Agron. J. 44:545-550.

Power, J. F. 1980. Response of semiarid grassland sites to nitrogen fertilization: II. Fertilizer recovery. Agron. J. 44:550-555.

Power, J. F. and J. Alessi. 1971. Nitrogen fertilization of semiarid grasslands: plant growth and soil mineral N levels. Agron. J. 63:277-280.

Power, J. F. and J. O. Legg. 1984. Nitrogen- 15 recovery for five years after application of ammonium nitrate to crested wheatgrass. Soil Sci. Soc. Amer. J. 48:322-326.
Rauzi, F. 1978. High rates of nitrogen change composition of shortgrass rangeland in southeastern Wyoming. J. Range Manage. 31:366-370.

Rauzi, F. 1979. Residual effects of phosphorus and high rates of nitrogen on shortgrass rangeland. J. Range Manage. 32:470-474.

Rauzi, F. and M. L. Fairbourn. 1983. Effects of annual applications of low $\mathbf{N}$ fertilizer rates on a mixed grass prairie. J. Range Manage. 36:359-362. Rogler, G. A., and R. J. Lorenz. 1974. Fertilization of mid-continent range plants, p. 231-254. In: D. A. Mays (ed.) Forage Fertilization. Amer. Soc. Agron., Madison, Wisc.

Rogler, G. A. and R. J. Lorenz. 1966. Nitrogen fertilization of natural grasslands in the northern plains of the United States. Proc. 9th Intl. Grassl. Congr. 1327-1330.

Samuel, M. J. and G. S. Howard. 1982. Botanical composition of summer cattle diets on the Wyoming High Plains. J. Range Manage. 35:305-308.

Samuel, M. J., F. Rauzi, and R. H. Hart. 1980. Nitrogen fertilization of range: yield, protein content, and cattle behavior. J. Range Manage. 33:119-121.

Smika, D. E., H. J. Haas and J. F. Power. 1965. Effects of moisture and nitrogen fertilizer on growth and water use by native grass. Agron. J. 57:483-486.

Smoliak, S. 1965. Effects of manure, straw and inorganic fertilizers on Northern Great Plains ranges. J. Range Manage. 18:11-15.

Steel, R. G. D. and J. H. Torrie. 1960. Principles and procedures of statistics. McGraw-Hill, New York.

Stevenson, A., K. E. Baumgartner, and G. E. Schuman. 1984. High Plains Grasslands Research Station, Cheyenne, Wyoming--Detailed soil survey. Wyoming Agr. Exp. Sta. Pub. 1-84/1C/ 3.62.

Tukey, J. W. 1953. Some selected quick and easy methods of statistical analysis. Trans. New York Acad. Sci. Ser. 2 16:88-97.

Wight, J. R. 1975. A summary of range fertilization research conducted by the Northern Plains Soil and Water Research Center, p. 1-6 In: Proc. Range Fert. Symp. Montana Agr. Exp. Sta. Res. Rep. 70.

Wight, J. R. 1976. Range fertilization in the Northern Great Plains. J. Range Manage. 29:180-185.

Wight, J. R. and A. L. Black. 1979. Range fertilization: Plant response and water use. J. Range Manage. 32:345-349. 